\title{
The Exercise of Power and Its Resistance in Isle of Dogs
}

\author{
Gracia Veva \\ English Department, Faculty of Languages and Literature, Petra Christian University, Siwalankerto 121- \\ 131, Surabaya 60236, INDONESIA \\ E-mail: m11415061@john.petra.ac.id
}

\begin{abstract}
This study attempts to show the forms of power exercised by a government and the resistance by the powerless in Isle of Dogs. In this study, I focus on power relations between the government led by Mayor Kobayashi and the powerless party which are the people and dogs. I address two problems which are the way the government exercises power and the way the powerless resists it. I use Foucauldian power relations and the concept of propaganda by Michel Sproule to help me analyze the problems. From the analysis, I find that power is exercised by the subjects who are able to manipulate others from their strategic position. I also found that power is fluid, and it transforms as it faces struggle and resistance. Finally, I find that in the field of power relations in a democratic society, people have a big role in determining the form and strength of the power that circulates in that society.
\end{abstract}

Keywords: Power, Resistance, Strategy, Democracy, Obedience.

\section{INTRODUCTION}

Animation is a genre of movies that is enjoyed by people of all ages, young kids to old people. It is often associated with childishness because of its unrealistic visual and storylines that often include imaginary characters and settings. The word animation derives from a Latin word, animare, which means 'to-give-life-to'. As its original meaning, it gives lives to the inanimate objects (Wells, 1998, p.10). Despite the "childishness", it doesn't mean that animation cannot represent reality. Wells argues that to give lives in animation production means transforming reality to the design and drawings, and that also means transforming the social reality of society. Among many interesting and unique animations movie, I choose Isle of Dogs, a work of a lagendary director , Wes Anderson. It is also a social commentary about a democratic government and its power.

Isle of Dogs takes place in the city of Megasaki, Japan, where an outbreak of snout flu has spread and infected dogs. All dogs are thrown and isolated in Trash Island under the command of the corrupted leader, Mayor Kobayashi. The dog-lover citizens and smart scientists make many attempts to cancel the decree. The dogs on Trash Island are being left to die from malign neglect. Among the sick dogs living in the island is a pack of 5 dogs, Rex, King, Duke, Boss, and Chief who later help Attari, the adopted son of Mayor Kobayashi who flies into the island in order to find his dog. After completing their journey on the island, they sail to the city where the counter-resistance to the suppressing power continues. Attari and the dogs join forces with a group of young protesters led by an exchange student, Tracy Walker, in order to expose Kobayashi's and other cat-lover government officials' corruption and cancel the decree of banishing dogs.

The movie gives an insight into a power relation in a democratic society led by a corrupted leader. A government has the power to control the people at a certain level in order to make sure the country or society is safe and in peace, and the right of the people is protected. Corstens noted that (p.10-11) in a democratic system, the power of government is limited by law and a written or unwritten constitution which those in power obey (2017). Even with the guarantees 
are given under the democratic system's law, leaders or people sitting in the government can still utilize the power and authority they have. In the movie Isle of Dogs, Mayor Kobayashi, a leader of the city, uses his power and releases the Trash-Island decree where he is able to remove dogs from the city, and as the reaction to the exercise of the power, the group of citizen and the dogs try to resist the change that happens by the government's exercise of power.

The story of Isle of Dogs shows a unique take on the power relations process between the powerless party which are the citizen and dogs, and the government as the powerful one. I decide to take this subject as the topic of my study. In order to analyze the exercise of power and the resistance in the movie Isle of Dogs, I am going to use the theory of Power Relations by Michel Foucault and the concept of 7 (seven) classic propaganda devices identified by The Institute of Propaganda Analysis.

Many people assume that power is something that is owned by people from upper class, or those who have high position in the government, that enable them to suppress people under them in order to gain their goals. However, according to Michel Foucault's theory of power relation, power is not owned and cannot be seized by others, but it is exercise trough many form of strategy in relations that exist in the society $(1978$, p. 94). Power is not possession that can be enjoyed by the elite, but it can be observed in an active act as the form of strategy that is done by some in order to achieve it goals. In another book Foucault explained that power is strategy that its act of domination is not an attribute to exploit others, but is an overall effect of its strategic positions and use as tactic that is carefully planned to achieve a specific goals (1977, p. 26). Strategic positions give access to knowledge that have an important role in the exercise of power. That is the reason why people with higher position or even the government seems to be powerful. However what the y have is access to knowledge and not power itself. This access can be also own by other who seems powerless. "Power and knowledge directly imply one another; there is no power relation without the correlative constitution of field of knowledge" (p.27).

According to Foucault the concept of resistance cannot be separated from power. Foucault argues that "when there is power, there is resistance" (1978, p.95). Resistance is the act of refusing to surrender or submit to the attack or influence of one party. Resistance exist trough actions as power is not exercise over passive bodies. Resistance inflames in a certain time, moment, and types of behavior and seen as the irreducible opposite of power (p.96). Resistances can exist at any points in the power relation and takes many possible forms in their own special case as an act of refusal to the exercise of power. Resistance is not simply a reaction of power existence, but it can bring change to the exercise of power. In the field where power operates, "power may transform, strengthen, or reverse through ceaseless struggle and confrontation" ( $p$. 92). When power is counter-attacked by the act of resistance, we can observe its fluidity as its trying to maintain its existence in a power relations that always change based on the situation and condition.

The government, the citizen, and the dogs in Isle of Dogs are connected on a power relation. I will use Foucault's theory of power relations to answer the question about the form of power exercise that exist in the relation of government, the people, and dogs in Isle of Dogs, and also the act of resistance as the counter-attack to the exercise of power by the government. Because the theory also explains about how power and the resistance may change and influences one another, I will apply the theory to analyze the changes that power may bring to the bodies on which it is exercised, and the form of power after it faces struggle and confrontation.

The secondary theory I will use is seven propaganda devices explained by J. Michel Sproule. Sproule (2001), in his essay Authorship and Origins of The Seven Propaganda Devices, discusses 7 (seven) devices or techniques identified by the Institute for Propaganda Analysis during the years 1937-1942 which are Name-Calling, Glittering Generality, Transfer, 
Testimonial, Plain Folks, Card Stacking, and Bandwagon. Propaganda may become one of the strategies used by the government in order to accomplish its goals. Three devices form the seven propaganda devices which is Name Calling, Card Stacking, and Band Wagon will be used to analyze the form of power exercise done by the government in the movie Isle of Dogs.

First, Name Labeling or Name Calling is conjuring hate or fear by attaching unattractive labels to those individuals, groups, nations, races, policies, practices, beliefs, and ideas which he would have us condemn and reject (Sproule, 2001, p.136). The negative labels are given to the targets to ruin their reputation or to ridicule it. The propagandist hopes the bad labels can form the audience's opinion without realizing it. Second, Card stacking is where the propagandist uses over emphasis and under-emphasis to put a calculated spin on his or her ideas or proposals (p.136). Here the propagandist may give an argument or information that full of facts in order to promote his ideas; however, the information that is given may not the fully accurate story. It has been distorted, but the people don't realize the changes. Last, Band Wagon is where the propagandist works to have people "follow the crowd," to accept an idea or plan because "everybody's doing it" (p.136). The positive impression of unity may become a center of this device. No one wants to be left behind, and no one wants to be labeled as the traitor of the group. This idea pushes people to be part of the crowd. Using Card Stacking and Name Labeling will be able to help the government to create a bad reputation for the dogs, and using Band Wagon can lead the people to do while hiding their true motive.

\section{EXERCISE OF POWER BY CONTROLLING PUBLIC OPINION AND THE RESISTANCE AGAINST IT}

The first strategy in exercising power by the government in order to achieve their goal is by controlling public opinion. Public opinion is an opinion of society's assessment of a political or economic problem. In the film Isle of Dogs which is set in a city with a democratic government system, the government plan to annihilate all dogs and replace them with dog robots. Mayor Kobayashi strives to get support from the public in the making of Trash Island decree, a decree which requires all dogs to be transferred to trash island. In order to do it, it starts to run some strategies to convince the public that the decree is necessary for the unstable and dangerous situations following the spread of dog virus.

\section{Controling People Opinion Using Propaganda}

In the movie Isle of Dogs, we are able to witness how a democratic government controls public opinion with propaganda. Propaganda in the movie Isle of Dogs is carried out primarily to manipulate public opinion and convince the public to approve the removal of all dogs into Trash Island using some devices of propaganda as its strategies. Among all the devices of propaganda that was elaborated and explained by Michel Sproule, there are 3 devices that can be found in Isle of Dogs: Card Stacking, Name Calling, and Band Wagon.

The first device of propaganda used by the government in Isle of Dogs is Card Stacking. On Card Stacking, some information is given and shared to the public as facts. However, the information is not necessarily an accurate or complete fact. In one of the news that broadcast the speech of Mayor Kobayashi about Trash-Island decree, the news anchor uses collected words to explain the virus that has spread in the city such as epidemic propotions, blizzards, ripping through the city, and threatening. The news puts an emphasis on the danger of the growth of the disease, and because of that, there should be an immediate action to overcome the emergency situation. However, there is no news about the origin of the virus, because the government try to cover it up. The truth is the virus is spread by the government themselves. 
The second device of propaganda that can be found in the movie Isle of Dogs is Name Calling. Name calling means giving bad labels to the individuals, groups, idea or more specific in the movie, the dogs in order to ruin its reputations. Reputations are representations tied to the subject as the community expectation (Fine, 2008, p.78). When a person is labeled with a reputation, bad or good, people will expect the person to act according to the reputation that the person holds. The reputation is shared among the community in social relations and shaped the community behavior to the subject. In the movie Isle of Dogs, we can find several posters that are used to describe dogs. The posters show the condition of the virus-infected canines.

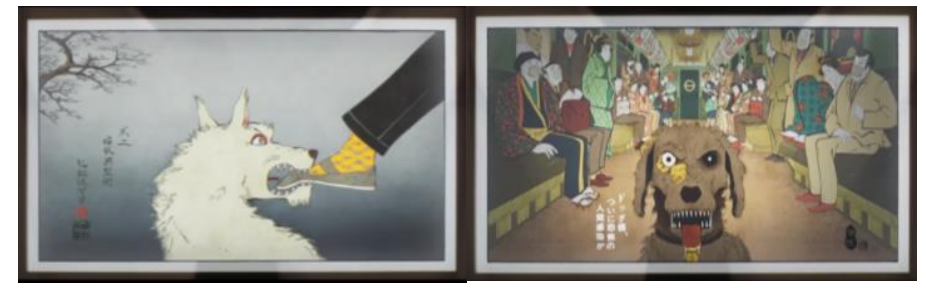

Picture 1. The Posters of the Dogs' Behaviour (Isle of Dogs)

On both posters above, the audience can see the dogs behavior toward humans. The first picture shows a dog biting a man's foot. It shows that dogs are aggressive and unsafe. The second picture shows a sick dog serounding by humans using masker. The dogs are not only dangerous but also disturbing to public comfort. All the posters show that dogs are no longer become the kind of animal that suitable as pets, but they are dangerous for the community and need to be isolated or even exterminated. This is how Mayor Kobayashi uses Name Calling to control people opinion.

The last propaganda device is Band Wagon. People, in general, have the tendency to follow the crowd or what seems to be the trends, and this is why Band Wagon become a great tool to control the public. After validating the Trash Island decree, Mayor Kobayashi does an action to prove that he is also part of the community and give the right example for the benefit of the society. It is announced to the citizen:

As a gesture of public solidarity, Mayor Kobayashi...furnish the personal bodyguarddog of the mayoral-household, Spots Kobayashi, into the possession of the Committee for Canine Desaturation. Spots will be the first dog to be officially deported from the city.

The word "public solidarity" is used as Mayor Kobayashi wants to show and emphasize that the action to alienate dogs, especially private dogs, is a form of support for the safety and interests of the community. Using the word "public solidarity", Mayor Kobayashi wants to emphasize and convince the public that there is an agreement among the public that it something that all people will do. Here shows how Mayor Kobayashi is able to use two simple words to promote his ideas through the Band Wagon.

\section{The Resistence to Exercise of Power by Controlling Public Opinion}

As the government exercises its power through propaganda and regulate the flow of the information in the society to control the public opinion, there are also efforts from the citizen to resist it. They see that the infected dogs are not dangerous to the public and that there are ways to handle the situation other than isolating the dogs. so, they try to give and spread information to oppose the Mayor and the government's ideas.

First, the resistance to the propaganda of the government come from Professor Watanabe through the speech that he delivers in the midst of the chaos that occurred among citizens who 
have been affected by fear of dogs. He stresses that the Trash-Island decree is unfair for dogs. Professor Watanabe tries to regain compassion and restore moral judgment towards dogs that have gone because of the hysteria that has been disseminated through reports about the disease. The second resistance to propaganda by the government comes from a group of Megasaki Senior High School students who tries to stop the spreading of false information and ideas by Mayor Kobayashi by using news media which are tv and newspaper. In order to stop and fight the propaganda that had been disseminated by Mayor Kobayashi, they sought to give evidence that Mayor Kobayashi has lied and manipulated the people.

In the attempt to complete his plan and get his goal which is removing all the dogs from the city, Mayor Kobayashi starts his exercise of power by controlling people opinion in order to gain support from the people. When the government exercises its power, resistance from some individuals or groups also happens. The acts of resistance may vary, but they have same purpose that is to convince the public that dogs are not dangerous and deal with the misinformation that the government have spread to the public in order to control their opinion.

\section{EXERCISE OF POWER BY FORCING OBEDIENCE AND THE RESISTANCE AGAINST IT}

The second form of power exercised by the government in the Isle of Dogs is forcing obedience by installing Manipulative Regulations. In principle, obedience is an act of submission to authority. Laws provide limits to the government and ensure the government does not exploit its people. But as the government must submit to the law, according to the Rule of Law, the people also have the duty to submit to the law and regulations that exist in the country. The relationship between the government and the people is not a transparent relationship. Because of that, the community cannot see the process of making regulations by the government giving the government a chance to manipulate the regulation.

\section{Forcing People and Dogs' Obedience by Installing Manipulative Regulations}

In the Isle of Dog film, Mayor Kobayashi is able to convince the Majority of the population of Megasaki if the dog is a dangerous animal and must be expelled even in a manipulative manner resulting in the installation of Trash Island decree. The installation of Trash Island decree is part of the government's strategy in order to succeed. The determination of manipulative regulation seems to be the perfect way to force obedience from both masters and dogs.

First, the government forces the masters of dogs by installing the manipulative regulation and emphasis they are responsible for community members and the consequences they might get. The dogs are dumped and removed to the island decree trash. The government uses public security issues that are spreading and moves all dogs to Trash Island without exception, and reinforces their decision through the ruling of the Island Decree Trash, a regulation made after manipulating the Majority of the Megasaki community. Dog owners who are also members of the community inevitably must follow the government's will because of their responsibility for existing regulations.

Second, manipulative regulation forces the dogs to obey in different ways than masters, as they are different in different levels of society and in terms of the law. The dogs are naturally obey their masters because the masters gives them food and cares helping them to survive. Because the dogs will follow what master's will, the government knows that as long they able to control the master, they will get access to control the dogs. Trough the enforcement of manipulative regulation, the government is able to gather all the dogs in one place which is the Trash Island. The control of the dogs is focused in one place. 


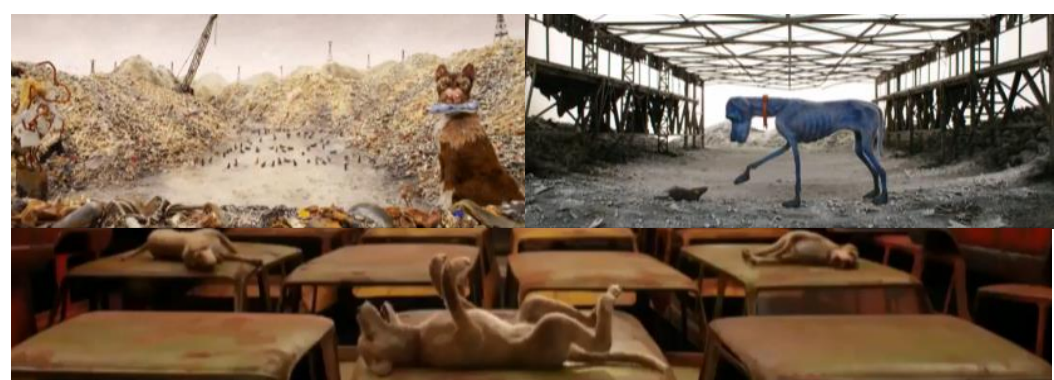

Picture 2. The Condition of the Dogs in Trash Island (Isle of Dogs)

Pictures above describe the condition of the dogs that were deported to Trash Island 6 months after the Island Decree Trash was released. There are drastic physical changes in the dogs after being exiled. These physical changes make dogs become weaker and lose their temper. Under the pressure they have, because of lack of food, the government will occasionally send food to them even though not in large quantities. This keeps the dogs waiting for help from the government. When they were miserable and seemed to be one step away from death, their only hope was that food from the government made them unable to fight the government themselves. But besides physical changes, the dogs are sadder, angrier, and desperate.

\section{Resistance to Government's Exercise of Power by Forcing People and Dogs' Obedience}

In order to achieve its goal of destroying all existing dogs, the government forced submission from pro-dog and dog supporters, but with the pressure that they have on them the masters and the dogs shows their act of civil disobediece as a form of resistance. Civil disobedience is an act of disobeying rules or authority but not accompanied by anarchic action. In this film some of the civil disobedience actions are from the dogs who refuse to lose hopes, and the dog owners trying to return the deported dog and trying to find ways to cancel the regulations made.

First, the form of the dogs' civil disobedience is by refusing to give in to situations and pressures formed by the government. It shows in a speech from a dog named Chief. For him, there is always a way to survive as bad as any situation. He uses the words "indestructible Alpha dogs", which means that even with the pressure from the governement, they are indestructible, and as alpha dogs, they don't need to depend on others because they themselves are leaders, at least leaders for themselves. They don't need to depend on humans, dog owners, or the government. The speech is able to bring back the other dogs' spirit to survive. The act of disobedience from the dogs also comes from a group of dogs who from the beginning have decided to fight for themselves and decide to end all the relationships they have with humans and the government.

Second, the act of civil disobedience comes from the pro-dog acivist who resist power government by looking for ways to cancel the regulations that have been set. After the decree was determined one way stop the government's plan was to find a way to cancel the regulations that had been set. Professor Watanabe's attempt to find a cure for dogs. This action is not a dangerous act, but the practice is done by Professor Watanabe and his colleagues are one form of civil disobedience because they try to challenge the regulations that have been set back. In addition, they also showed their defense and support for dogs that were subjected to government regulation.

Third, as the resistance to the power exercised by the government, Mayor Kobayashi's adopted son, Atari Kobayashi, flies to the Trash Island on a mission to bring back his dog. The regulation made by Mayor Kobayashi clearly says that all dogs must be deported to Trash Island, and Spot, Atari's pet dog becomes the first dog deported to Trash island. Atari, who does 
not accept this, secretly made a rebellion and went to save his dog. Pro-dog activists ensure that Atari's act of disobedience is broadcast and known by all residents of Nagasaki.

Facing the resistance from some parties as the government exercise their power, they strengthen their strategies by forcing obedience from the people and dogs through manipulative regulation. Though it is manipulative as the regulation is made for a hidden unjust reason, it is still counted as a regulation with strong legal stands. It shows how power becomes stronger as it faces resistance and struggles. Not only power but the resistance also changes. The opposite parties must know that the government tries to regulate and control their lives, so they start the act of disobedience. It shows that exercise of power and resistance are two things that cannot be separated. Both affect one another and keep changing according to the situation that they face.

\section{EXERCISE OF POWER BY INSTILLING FEAR AND THE RESISTANCE AGAINST IT}

The third way the government does exercise its power is by spreading fear. Fear can be one of the things that can encourage someone to do something. Fear makes us aware of the danger, be careful, and get ready for all sort of actual and potential threats. The government uses the public's fear of the danger from abroad or the instability of the domestic situation to persuade its people to obey the rules. This fear was the source of power for the government in the Isle of Dogs film Dogs as they started their act of violence.

\section{Instilling Fear by Using Violence}

Violence is an action in the form of a physical force that aims to hurt or kill someone or something, but violence also aims to instill fear. In the previous sections, we saw that the power perceived by the government in the film Isle of Dogs was more subtle and less visible to the public. Even when they force the obedience of dogs and dog owners, they use manipulative regulations to cover their plans. But after power exploited experienced struggle and resistance, the government must strengthen their power, and a form of violence emerged where the pressure exerted by the government was more visible through the fear they spread. In the film, the government uses two actors to spread fear using violence, namely non-state actors and state actors.

First, non-state actors are individuals or groups that have no relationship with the government and the government does not need to take responsibility for their actions, however, they have influence in society. In the film Isle of Dogs, the government used help from an alley called the Clenched-Fist Gang. One of the acts of violence committed by non-state actors is the murder of Professor Watanabe. Professor Watanabe is killed after he and his assistant find out about government's evil plans. Professor Watanabe's murder may have been done so he did not disseminate the information, but the murder was also a warning to his other colleagues.

Professor Watanabe himself is the candidate of the opposing party and is an important figure in the Pro-dog campaign. His death is a warning to other protesters to stop their resistance to the government's power.

Second, to instill fear, Mayor Kobayashi's government also uses state actors who are individuals or organizations under the government and act on behalf of a governmental body. As part of the government, the State actors cannot act as they wish and harm other's rights. They are regulated by regulations stipulated by the government. dogs that are basically labeled as public enemies. 


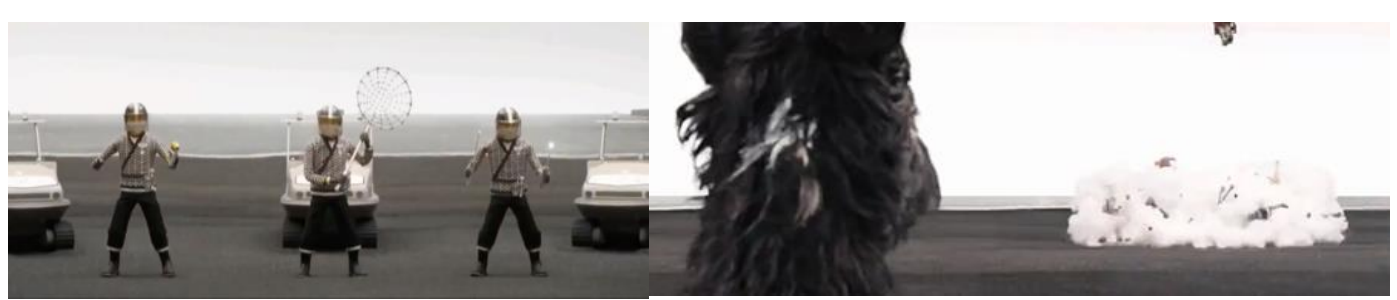

Picture 3. The Government's Act of Violence to Capture the Dogs (Isle of Dogs)

Above is a scene where the Military Force tries to capture the dogs that oppose the government. The command is to capture and violently destroy the dogs who disobey the government. This shows that the government was serious in carrying out their plans and acting decisively on every effort to publish their plans. It was also a warning to other dogs and pro-dog activists that the dogs caught fighting and trying to flee from Trash Island would be killed. Mayor Kobayashi's government instilling fear with the strategies he had and those he could rely on both non-state actors and state actors.

\section{The Resistance to Government's Exercise of Power by Instilling Fear}

Mayor Kobayashi tries to stop protesting them, but they choose to resist And after the various forms of resistance, they have done to stop the government's efforts failing, they have made a stronger and more presumptuous resistance effort. In their resistance to fear of violence, they chose to fight back with violence and non-violence acts. The two actions is resulting in the reformation in which they tried to bring down Mayor Kobayashi from his position.

First, the dogs use violence when they resist to the military force who want to arrest them. Dogs are in desperation because there seems to be no other way out for them, physically fighting. Violent act as resistance results in chaos as two parties that have the power each refuse to back down in a power relation. The same thing often happens in demonstrations that end in chaos, because it seems that the opinions and ideas they promote in demonstrate are not heard at all.

Second, the pro-dog activists use nonviolence actions to remove Mayor Kobayashi from his position. Atari and the pro dog activists speaks in front of the people who had gathered to support Mayor Kobayashi. They show the cure developed by Professor Watanabe, they prove that the news about Atari is being kidnapped is wrong, and they also assure everyone that while Atari was on Trash Island, he was not hurt or harmed by dogs as Mayor Kobayashi has said. This is done to convince the people because the government in Megasaki is a democractic government and the people holds the greatest power in making all decision. When Atari and his friends were able to convince the public and the community to agree, Mayor Kobayashi has naturally lost the support from the people.

With the help from non-state actors and the state force, the government try to silence the opposite parties using their sense of fear for their own lives. As the act of resistance to such an act, the dogs can only use violence to counter the exercise of power and the pro-dog activists and Atari meet face to face with Mayor Kobayashi and open his bad deed in front of all people. As the dogs and the pro-dog activists succeed to get their goals, we can see that high position and status does not determine that someone has power over others permenantly. It may give him a strategic place with access to better strategies, but it does not mean that he can always hold the power.

\section{CONCLUSION}

From the analysis, it can be concluded that the government led by Mayor Kobayashi in the movie Isle of Dogs's exercise of power manifests in the act of controlling public opinion, 
forcing people and dogs' obedience, and instilling fear. The exercise of power happens as the government try to achieve their goal which is to exterminate all the dogs. The exercise of power varies depending on the understanding of the goverment on the situation and condition of a democratic government. In Isle of Dogs, as the government exercise their power, counterattacks come from the parties that oppose the government's work and plan to exterminate the dogs as an act of resistance. The acts of resistance mainly come from the pro-dog activists, the dog lover scientists led by Professor Watanabe, and the dogs themselves. The resistance comes through speech, tv news, newspaper, act of obedience, and violence. Pro-dog people and dogs have their own strategies againts each exercise of power by the governent.

The proves shows that, first, the exercise of power and the resistance are seen through tactics and strategies that are implemented to achieve goals. In exercising power, position and status is not the most important thing. Knowledge is the most important one in order to build a strategy. Second, power changes as it goes through resistance and struggle which shows power's fluidity. The government, citizens, and dogs as the subject in the power relations keep coming up with a better strategy in the field of power to attack the opposing sides. Lastly, I find that people have a big role in power relations in a democratic country. From the start when the government exercise their power, the government need support from the people, and Mayor Kobayashi steps down from his position and admits his loss after the people stop supporting him. From the movie Isle of Dogs, we can see that animation is not just a childlike entertainment for kids, but it also features great storylines that are full of important ideas and ideology. It can be a social commentary that become a criticism of a certain situation in the society.

\section{REFERENCES}

Corsten, G. (2017). Understanding the Rule of Law. (A. Mills, Trans.) Oxford and Portland: Hart Publishing.

Fine, G. A. (2008). Reputation. Contexts, vol. 7, no. 3, 78-79. Retrieved April 26, 2019, from https://www.jstor.org/stable/41801221

Foucault, M. (1977). Decipline and punish: The birth of the prison. (A. Sheridan, Trans.) New York: A Division of Random House, Inc.

Foucault, M. (1978). The History of Sexuality Volume I : An Introduction. (R. Hurley, Trans.) New York: Pantheon Books.

Sproule, J. M. (2001). Authorship and Origins of the Seven Propaganda Devices: A Research Note. Rhetoric and Public Affairs, 135-143. Retrieved March 13, 2019, from https://www.jstor.org/stable/41939653

Wells, P. (1998). Understanding Animations. Abingdon: Routledge. 